DOI: $10.31558 / 2308-1902.2018 .26 .4$

УДК 821.161 .2

Наталія СКВIPA

кандидат філологічних наук, старший науковий співробітник, Інститут літератури імені Т. Г. Шевченка НАН України

\title{
УКРАЇНА, СИБІР І ДАЛЕКИЙ СХІД У ТВОРЧОСТІ ІВАНА БАГРЯНОГО ТА ВАСИЛЯ СТУСА
}

У статті на прикладі роману «Тигролови» Івана Багряного і «Палімпсестів» Василя Стуса досліджується топос Сибіру, Далекого Сходу і України.

Сибірсько-далекосхідний край трактується як місце заслання, переселення, а також пов'язується 3 «духовним освоєнням» (своєрідним «воскресінням» (за Лотманом)), що є реалізацією дихотомії «своє-чуже»: віднайдення нового місця («Тигролови») чи повернення до рідного («Палімпсести»); його природа оприявнюється у творчості обох майстрів слова за допомогою констант незвичності, екзотизму, відмінності від свого, українського.

Ключові слова: топос, Сибір, Далекий Схід, Україна, дихотомія «своє-чуже».

О краю мій, великий, як Сибір, хай шир твоя не для Сибіру - вірю, та поки кожен шлях изей не проміряє не запануе у Вітчизні мир.

B. Cmyc

Світ надовкола не святиться, узгір'я сопок долі гне.

B. Cmyc

Художніми константами образу Сибіру в українській літературі є чужий край, топос несправедливого покарання, переселення (виселення), загрози, страху, пекла. 3 іншого боку, саме перехід через сибірські «дантові кола» чи перебування в них символізують героїзм, мужність, нескореність, самовизначення тощо.

Інтерес до сибірського дискурсу та його усталення в українській літературі ХХст. великою мірою спровоковані соціально-політичною ситуацією «поневолення», пов’язаною передусім із численними репресіями, депортаціями українського народу в радянські концтабори. Найбільшого розмаху такі переселення набули за часів Гетьманщини (П. Калнишевський, Д. Многогрішний, П. Полуботок, І. Самойлович) та у другій половині XIX - 
початку XX століття, особливо після спорудження Транссибірської магістралі. За даними переписів населення, у 1897 р. у Сибіру мешкало 223,3 тис. українців.

Сибір у літературознавстві інтерпретується також як кульмінація життєвої долі, своєрідне «очищення», передумова «воскресіння». Послуговуючись відомою формулою Ю. Лотмана, міфологічну схему «смерть пекло - воскресіння», яка б мала заміщуватись новою, а саме: «злочин заслання до Сибіру - воскресіння» $[7,338]$, можна «накласти» і на сюжети творів української літератури з сибірською темою, принаймні конкретизуючи першу складову схеми «злочин» крізь призму тогочасної ідеологічної обстановки.

Звернення до зазначеної теми зумовлене також перебуванням багатьох українських письменників та поетів на засланні на Соловках, в Сибіру (П. Грабовський, М. Куліш, В. Стус, С. Плужник, В. Підмогильний, Г. Косинка), адже після проголошення Валуєвського циркуляру (1863р.) російським урядом переслідувався фактично кожен український письменник.

Одна Сибір неісходима,

А тюрм! А люду... Що й лічить!

Од молдованина до фінна

На всіх язиках все мовчить,

Бо благоденствує, - писав Т. Шевченко у поемі «Кавказ»

$[11,345]$.

Ю. Горова зазначає: «В романтичному дискурсі топос Сибіру мав як демонічний, так і сакральний аспекти. Демонізація виражалася в ототожненні його 3 простором абсолютного зла, що, своєю чергою, давало можливість чинити йому опір, а отже, прилучатися до святої справи. Саме романтикам належить провідна роль у символізації та сакралізації образу Сибіру...» $[4,56]$.

Ще один аспект сибірсько-далекосхідної теми, що відобразився на сторінках творів української літератури XX століття, - життя українських переселенців. Саме про такі переміни долі оповідає один із персонажів 
«Тигроловів» Івана Багряного Сірко: «Рідну землю покидали, уклін їй складали, береги сльозами поливали і довго-довго руками та шапками з моря Чорного махали, у краї чужі, далекі, за тридесять земель-морів, на край світу мандрували, щастя-долі шукали... Для початку з половини перемерли. А далі позвикали. А позвикали - то й зажили! Ого! Ще й як зажили!» [3, 141].

Крізь призму топосу Сибіру можна інтерпретувати творчість Б. Антоненка-Давидовича, В. Барки, І. Багряного, П. Богацького, К. Буревія, П. Грабовського, Є. Плужника, М. Стельмаха, В. Стуса та ін. Об’єктом нашого аналізу є роман Івана Багряного «Тигролови», який розкриває панораму життя українців-переселенців, та поезії Василя Стуса, що уможливлюють бачення Сибіру очима засланця. Обидва майстри слова були арештантами. Багряний відбував заслання на Далекому Сході серед українців Зеленого Клину та в Бамтабі [2], Василь Стус-у мордовських і магаданських таборах.

Іван Багряний починає свій роман з опису двох «драконів-експресів»: перший - «ешелон смерті», в якому серед в'язнів зустрічаємо юнака 25 літ Григорія Многогрішного, «гордого нащадка першого каторжанина Сибіру, правнука гетьмана Дем'яна Многогрішного»; другий - «Тихоокеанський експрес нумер один «Нєгорєлоє - Владівосток», пасажири якого «...інженери i авіатори, ударники i так літуни, партробітники i туристи, колгоспні колективізатори і радгоспні бюрократи, раціоналізатори й індустріальні авантюрники, прокурори і розтратники, потенціальні злодії й імпотентні фарисеї... Цивільні і військові <..> Шукачі карколомних пригод, а ще більше карколомних кар'єр. Шукачі щастя і довгих карбованців <...> Словом - цвіт робітничо-селянської імперії у всій його величі і багатогранності. Все те різне віком, фахом, статтю і уподобаннями, але все тут має спільну рису - рису шукачів чогось і збігців кудись, - рису шукачів щастя i збігців у невідоме» $[3,18]$.

У творі письменник розкриває причини появи українців у далекосхідному регіоні: «...Професор історії... викладав, як легенду, історичну довідку про перших-найперших каторжників Сибіру, про перших-найперших 
політичних засланців, що склали тут свої кості, і саме в цім Забайкаллі, в цім найсуворішім і найпонурішім закутку Східного Сибіру. I було їх двоє, тих піонерів: навіжений протопоп Аввакум... Але цей розкольник був другим. А першим був - бунтар і “ізмєннік” - “малоросійський” гетьман на ймення Дем’ян Многогрішний. Це вони були відкривателями і зачинателями тієї жахливої сторінки... в епопеї невимовних людських страждань на цій землі...» [3, 26-27]. Родина Сірків, мешкаючи на чужині, добре пам’ятає, як жили їх славні пращури «на Полтавщині, коло славного города Переяслава», «як i діди, і прадіди ще жили - в Запоріжжі козакували, на Крим і в Туреччину ходили, на “ночвах" море перепливали та страху усім наганяли, та ще й на галерах не раз бували і звідтіля утікали... А потім і онуки на галерах попливли тим морем Чорним...» $[3,141]$.

«3 образом Сибіру, завдяки історичній обумовленості - більш пізньому приєднанню сибірських територій до центральної Русі, навмисне пов’язують у літературі мотиви “відкриття”, “осягнення”, “пізнання” нового світу. I в цьому сенсі протягом багатьох віків Сибір сприймався письменниками й художниками як “нова земля”», - зазначає Р. Ертнер [12]. У «Тигроловах» Іван Багряний докладно змальовує особливості зміни довкілля: «Мінялись краєвиди, мінялись настрої; мінялась флора, люди, обрії. Все вражало новиною, щораз, то чудовішою. За Уралом спостерігали сніг на вершинах гір... У Вятці спостерігали в натурі той фольклор, що звикли його бачити в столичних крамницях народної творчості. I купували його скільки хотіли тепер: купували гармонійки i гармонії, свистілки i сопілки, купували вибагливі дрібнички - дерев’яні, паперові, глиняні, ликові, розмальовані, випалені, різьблені генієм вятської російської цивілізації <..> На кожній станції, де тільки експрес зупинявся, щось було нове, таке, що ще ніхто не бачив з них. Пасажири вибігали геть з усього поїзда, розхапували всю ту новину, всю ту екзотику і напихали нею експрес [3, 23-24].

Не зовсім звичним, проте промовистим $є$ опис місцевості у «Палімпсестах» Стуса: 
Навпроти графіка гори

і сніг і чорні сланці,

о хоч на мить заговори,

чиї лежать тут бранці.

Там, за розпадком, за горбом,

блаженний паділ дикий,

чиїм розораний ребром,

чиїм продертий криком?

О чорна графіка гори,

о мерзла кров пролита,

заговори, заговори,

повідж, кого тут скрито.

Яка священна таїна

про злочини бувалі!

Аж стягне темінь навісна

у виглухлім проваллі [9, Т. 3, Кн. 1, 147].

3 вікон ешелону герої «Тигроловів» споглядають Бамтаб. Ось вони, каторжники, «справжні, реальні, невигадані і - незчислимі. Як розгадка болючої і жаскої таємниці. Як сама таємниця, на яку страшно було дивитись... А вони стояли безконечними шпалерами, безконечною тичбою вимучені, виснажені... В химерних і страшних бамлагівських одностроях: в ганчір'яних шапочках-ушанках і в такім лахмітті, що здавалося, ніби їх рвали всі собаки всього світу і тріпали всі сибірські й транссибірські вітри та буревії» [3, 28]. Про страхітливі каторжанські епопеї, про «силу-силенну “своїх людей” - земляків 3 далекої тієї України нещасливої... Про голод і цингу... Про надлюдські терпіння і труд каторжний, а надто взимку, при 50ступневому морозі напівголих, напівбосих людей, чесних трударів полтавських, та катеринославських, та херсонських “куркулів”, “державних злодіїв”, суджених “за колоски”, та й всяких “ворогів” - вчених, вчителів, 
селян і робітників, бородатих дідів і таких же бородатих юнаків, що й не розбереш, скільки людині віку... Про жорстоку смерть без похоронів, як худоби, - смерть від знущання, голоду, пошестей і журби... Про здичавілих собак, що тягають мерзлі людські голови і руки межи бараками... Про чуті арештантські пісні і тугу без слів (бо давно виплакані)... Про неймовірні самогубства...» $[3,112]$ повідає старий Мороз.

У «Палімпсестах» Василя Стуса знаходимо подібні картини:

І що кигиче в мертвій цій пустелі?

Киги-киги - мов чайка 3-над Дніпра.

О семигори горя, цвинтар велій, і я тут згину, як прийде пора?

Киги-киги - за ким ти тужиш, пташко?

Киги-киги - й тобі своя біда?

Потерпимо іще - бодай і тяжко,

тут наша кров - солона і руда.

Сюди ми йшли - займанщину обсісти, козацькими кістками облягти.

Живцем, як кажуть, в землю ж не залізти -

Сибіру, Магадану чи Ухти.

Кигикнуло - і далі полетіло.

А, може, все причулося мені?

І вже болить душа, на дуб здубіла,

в цій чужаниці, чужбі-чужині! [9, т. 3, кн. 1, 119].

Сибір у творчості Івана Багряного й Василя Стуса представлений переважно за допомогою стійких домінант північного простору та пейзажу (пор. «О краю мій, великий, як Сибір» (В. Стус), «Бо $є$ у сибірських квадратах / радісний небокрай» (В. Стус), «[Дракон гнав]... Через хащі Сибіру... у чорну сибірську ніч, на край світу» [3, 7]; «..женуть вони отак божевільним темпом через глуху ніч і крізь ще глухіший Сибір, оповиті таємницею... Не просто таємницею, а таємницею державною оповиті вони. 
Обставлені багнетами, устатковані прожекторами, женуть вони десь у таємницю ж, непроглядну, як сам Сибір чи як тая сибірськая ніч» $[3,9]$.

Епітетний ряд семи «Сибір» посилюється означеннями «чужинецька земля», «чужаниця», «чужба-чужина», «біда», «мертве царство» (В. Стус), «сибірське пекло», «страшний край і страшне життя тут» («Тигролови»), «холодна каторга» («Сад гетсиманський»).

Сибірська природа втілює холодність та суворість обставин, таїть невідоме майбутнє, сповнене «морозами, острахом» (В. Стус). М. Азадовський у статті «Поетика “пропащого місця”» слушно зауважує: «Сибір сприймався в основному як страшна та сувора країна, як похмурий край вигнання й заслання» $[1,166]$. Українська література XX ст. продовжує протопопівську, короленківську, рилєєвську, шевченківську традицію змалювання понурого, холодного пейзажу Сибіру.

Природа Сибіру й далекосхідного краю у творах Івана Багряного та Василя Стуса також описується як екзотичне, парадоксальне явище: «Чи думав ти... що поженеш їх за тридев’ять земель, за незчисленні пасма гір, несходимі простори пустель і нетрів з родичами та “со чадами” завойовувати, опановувати і посідати той - відкритий тобою - світ, той опоетизований Клондайк і заразом едем... Так, едем, де росте виноград і клюква, коркове дерево... полярна береза, живе субтропічний барс і гімалайський ведмідь, ще й полярний “урсус арктос” на придачу; шляхетний олень і сніжний горал; тендітний єнот і сестра гієни - росомаха тощо... Край - як гарячкова фантазія п’яного, як маячіння божевільного. Витвір космічного жарту, а чи плід космічного катаклізму, а чи то плід всесвітнього гумору. Край парадоксів. Симбіоз субтропічного раю і сибірського пекла...» $[3,23]$.

У епістолярії Василь Стус так означив своє місцезнаходження: «Ось такі сопки (гори) оточують моє селище, де я вже два тижні призвичаююсь. Зовсібіч - сопки, за горбами нічого не видно, нічого й не чути. Фауна - вічної мерзлоти. Флора - так само. Мушу й сам навічно замерзнути, аби призвичаїтись. Мешкаю я за 400 км на північний захід од міста Магадана, 
недалеко од місця, де зачинається річка Колима (ближче до мене є річка Тулу). Краєвид чимось нагадує Рокуелла Кента - так мені видається по далекій пам’яті» [9, т. 6, кн. 2, 97]; «Саме слово Колима годилося б поукраїнському перекладати: халепа, так гадаю» [9, т. 6, кн. 2, 98].

Образ Колими часто постає у «Палімпсестах» автора: «Ой ти, горе голодне, / навісна Колима! / Не мине тебе жодне / із нещасть. I нема / ані душечки близько - / ні братів, ні сестер./ Сонце никає низько - / від печер до печер. / Тільки сопки горбаті, / лиш зав’юга та сніг, / тільки сни пелехаті, / од яких ти знеміг. / А далека Вітчизна, / як зигзиця, ячить / і година стогрізна/ навперейми спішить» $[9$, т. 3 , кн. 1,177$]$. Або:

Довкола сопки і хрести, людські кістки біліють щедро, од божевілля й німоти малесенький рятує бедрик.

I що ти скажеш, Колимо, що мовиш ти, іване-чаю? Квадратним строєм ідемо, цвинтарне сяйво нас вінчає.

Як вигорбатів суходіл, довкола - скрем'янілі зойки, постигли обрії безокі, ми в падолі живих могил [9, т. 3, кн. 1, 150].

На сторінках роману Багряний описує тайгу Уссурійського краю: «Височенна, чотириярусна тайга, буйна й непролазна, як африканський праліс, стояла навколо зачарована. Не шелесне лист, не ворухнеться гілка. Сорокаметрові кедри, випередивши всіх у змаганні до сонця, вигнались рудими, голими стовбурами 3 долішнього хаосу геть, десь під небо і заступили його коронами. Там по них ходило сонце і пливли над ними білі хмари. Слідком за кедрами пнулися велетенські осики та інші листаті гіганти, що, бувши нижчі за кедри, творили другий ярус. Потім височенна ліщина колючого горіха, ялини, 
де-не-де берізки, берестина, черемха, перевиті ліанами дикого винограду та в’юнків, ішли вгору третім ярусом. А внизу - в четвертому ярусі - суцільний хаос. Місцями густа, мов щітка, звичайна ліщина, височенні трави і бур'яни. Повалені вздовж і впоперек дерева, мов велетні на полі бою, потрухлі і ще непотрухлі, одні з скрізними дірами-дуплами, як жерла небувалих гармат, другі вивернуті з усією системою коріння, що тримали його руба, як стіни або як велетенські пригорщі зі стиснутими межи пальцями камінням і землею. Внизу, по землі, слався мох, пообростав усе, що тільки можна. Внизу було півтемно і вогко. Лише де-не-де проривались яскраві сонячні пасма і стояли, як мечі, уткнуті лезами в землю. Нетрі. Несходимі, незміряні [3, 40-41]. Саме у змалюванні пейзажів Далекого Сходу, на думку М. Сподарця, виявився фах Багряного-живописця $[8,48]$.

Світ тайги незвичний для читача: солонці (низові узбіччя голої сопки), гарі (вигорілі нетрі), марі (гірські багна). Тваринний світ (горали, козулі (сарни), паути, ізюбри (олені), вивірки, гнус (мошкара), харна, таймень, харюзь, горностаї, сарни, клоктуші (качки), колонок (звір з родини тхорів), солонгой, харза (куниця), щитомордник (гадюка), тетеруки, фазани, нерпи, россомахи, летяги), як i рослинний (дикий часник, женьшень, саранки, кипрей (квіти), чорна береза), вражає своїм різноманіттям.

Понура, холодна Сибір гармоніює з сильними, витривалими, мужніми характерами героїв твору «Тигролови». В основі сюжету - доля засудженого українця Григорія Многогрішного, який, утікши 3 етапного ешелону, потрапляє до родини тигроловів Сірків. Григорій підмічає всі тонкощі життя

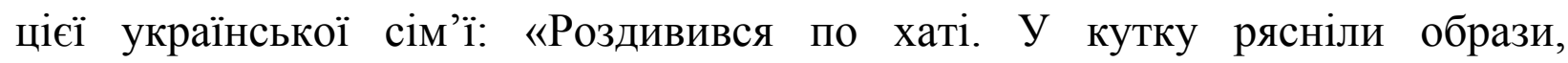
королівськими рушниками прибрані, кропило 3 васильків за Миколою Чудотворцем. Чорні страстяні хрести напалені на стелі... Пахне васильками... Мати в очіпку і в рясній стародавній спідниці, посміхаючись, несе тарілки в двері... За нею бистроока дівчина виступа, мов горлиця... Біля вікна, тримаючи козацьке сідло й ушивальник, звівся і стоїть густобровий, кремезний парубок <...> 
- Де це я? - прошепотів Григорій розгублено, злякався за свій розум.

- Та в нас же, в нас дома, сину... На стіні рясно карток - дівчата у вишиваних сорочках, у намисті, парубки в шапках і киреях.

- Який... Який це район?

- Та Київський же...» [3, 55-56].

Григорій розумів, що він не вдома, але все здавалося йому надто близьким і знайомим. Згодом він дізнається, що потрапив у містечко, котре «Києвом зветься..», що в «селах тутешніх хати білені зокола, як на Україні», що цей «край працю любить та й винагороджує іï щедро...І ліс, i золото, i риба, і земля хліб родить, і ягода всяка, і все - бери тільки...» $[3,73]$. Дізнався Григорій і про те, що ця земля стала для Сірків їх «другою Україною, новою Україною... але щасливішою»: «І назви наші люди подавали тут свої, сумуючи іноді за рідним краєм: Київ, Чернігівка, Полтавка, Україна, Катеринославка, Переяславка тощо. Тут, де не поїдеш, - то з Києва виїдеш, а в Чернігівку приїдеш, з Чернігівки виїдеш - в Полтавку приїдеш, в Катерино-Славку, в Переяславку... По всім Уссурі і по всьому Амуру, як дома... Але це там, де все люди наші осіли понад річками, де можна сіяти хліб. Жили! Жили ми, синку!.. Ну, а потім пішло все шкереберть... Десь прогнівили Бога. Нові часи, нові порядки. I настало таке, що люди за голови хапаються. Прийшла совєтська власть і все перевернула. Перевелись люди, і звелось життя нінащо... Вже немає Сіркової держави, гай-гай...» $[3,74]$.

Г. Клочек відзначає: «“Тигролови” - один з тих нечисленних творів, який дарує нам образне бачення “трудів і днів” українських переселенців, що утворили на Далекому Сході величезний за розмірами край під назвою Зелений Клин» $[6,4]$. Родина Сірків не лише освоїла чужі землі, а й навчилася полювати на тигрів, лучити рибу, будувати житло. Окреме місце в романі займає детальний опис пантування - полювання на ізюбрів (оленів) заради їхніх пантів (рогів), які використовують для виготовлення спеціальних ліків. Гриць Сірко знається також на фольклорі цього краю, про 
що свідчить його розповідь про дівчину-удегейку, яка через нерозділене кохання стала водоспадом.

Звичаї «Сіркової держави» грунтуються на українських: сім’я Сірків гостинна, їх закон - «Моя хата - твоя хата» [3, 59]: «Е, синку, тут такий закон, закон неписаний. Тут раніше було хоч рушницю залиши у шатрі, хоч хутрину, хоч що хоч, - лежатиме місяць - ніхто не візьме. Бувало, й зайде хто, - переспить чи дощ перебуде та й піде. Було... Та й тепер ще, слава Богу, поки без великих змін. Так же колись і на Україні було... Чи, мо', й тепер?..» [3, 120]; багата обідня трапеза, страви та подяка Богові за хлібсіль: «Стіл був застелений скатертиною і заставлений, як на Великдень... Пили наливку і їли оселедці 3 оцтом. Потім гарячий борщ, локшину 3 білими пирогами, сите м'ясо з картоплею. Далі: пироги з рижем, з м’ясом, 3 квасолею. А на закуску солодке - мед i солодку брусничну... Потім повставали, перехрестились до ікон і стали збиратись» $[3,88]$; різдвяні віршівки Сірка $[3,168]$. Господа Сірків («Стара, але дебела ще хата, рублена 3 доброго дерева, з різьбленим ганком і такими ж наличниками коло вікон, крита гонтом... Праворуч - дебела комора з омшаником, повітка для коней, корівник, стіжок сіна, обгороджений латами, ще якісь будівлі. Ліворуч город, теж обгороджений в одну лату. Ще й глечик стирчить на ближнім стовпці. В городі картопля і соняшники, а просто над самою річечкою якась комірчина: то лазня “по-чорному”» [3, 69]) нагадує українські дворища. Навіть загін чоловіків у папахах та 3 рушницями видається Григорію за уссурійських козаків [3, 64], а в жилах сміливої Наталки, на думку героя, тече «козача кров» [3, 67].

Діалог Григорія та Сірчихи: «- Я от скільки днів дивлюсь на оцю хату вашу - і мені якось дивно. Всередині вона вибілена, ще й розмальована понашому, а зокола - вигляд сибірський або поліщуцький. - Я сама, синку, довго не могла звикнути, не по-нашому це. Але ж це ми тільки тут так. А як жили в селі... Тепер це містечко Києвом зветься... Так там, та й у всіх наших селах тутешніх, хати білені зокола, як на Україні. 3 нас за це всі тут сміялись, 
що от, мовляв, скільки лісу, а “хохли” хати з глини ліплять та білять. Ні, тут хати зовсім такі, як на Україні. А не раз і кращі, бо на дощанім помості і криті здебільша цинковою бляхою» $[3,73],-\epsilon$ виявом дихотомії своє-чуже на побутовому рівні. Ще одним прикладом, що являє собою взаємопроникнення елементів культур і водночас може трактуватись як опозиція «своє-чуже», можна вважати звичку тубільця Кім-Гу-Суна «співати своїм диким фальцетом “Розпрягайте, хлопці, коні...” - єдиної “рюської” пісні, яку він умів добре співати, навчившись іiі від червоноармійців на маньчжурському кордоні, i найпоширенішої в цілім цім Далекосхіднім краї. Григорій слухав той спів 3 неабияким зачудуванням. Кім-Гі-Сун навіть не запідозрював, яке надзвичайне, яке колосальне вражіння той його п'яний ще й фальцетовий спів справляє, яку силу думок він родить... Тільки в устах чужинця, та ще такого далекого, дикого азіата, рідна пісня набуває враз якогось виїмкового значіння і змислу» [3, 171-172].

Урбаністичний аспект означеної опозиції оприявнюється також в іншому епізоді. Наприклад, Хабаровськ Григорію сподобавсь, бо він «дуже нагадував Київ», а його головна вулиця скидалася на Хрещатик $[3,181]$. Саме у японській ресторації цього міста, що йменувалась «Українська Слободка», Григорій зустрічає молодих українських дівчат: «Дівчата говорили українською мовою! I так, ніби хто врізав батогом по серці, ніби обухом по карку: "Та це ж вони!!! - дочки розкуркулених батьків, розкиданих по Сибірах! Це ж вони, втікаючи, Рятуються! Рятуються від голоду й холоду, від безправ'я і смерті, - рятують життя ціною краси і молодості, ціною честі і материнського щастя...”» $[3,198]$.

Неодноразово у «Палімпсестах» звучить мотив туги за рідною землею:

Коли б, коли б ви мали, голуби, хоч трохи серця - ви б його на крила взяли до себе і перенесли на Україну, геть за ним стужілу [9, т. 3, кн. 2, 77]. 
Рідна Україна, Київ є невід’ємною частиною спогадів Василя Стуса:

За мною Київ тягнеться у снах:

зелена глиця і темнава червінь

достиглих черешень. Не зрадьте, нерви:

попереду - твій крах, твій крах, твій крах.

Лежить дорога - в вікових снігах,

і простори - горбаті і безкраї

подвигнуть розпач. О, мій рідний краю,

ти наче смертний посаг - в головах.

I сива мати мій куйовдить страх.

Рука іï, кістлява, наче гілка

у намерзі. Лунає десь гагілка

і в сонці стежка. Й тупіт у степах [9, т. 3, кн. 1, 101].

Нерідко у творчості Багряного та Стуса очевидне також протиставлення пейзажу свого, рідного, українського - чужому, далекому.

На колимськім морозі калина

зацвітає рудими слізьми.

Неосяжна осонцена днина,

і собором дзвінким Україна

написалась на мурах тюрми.

Безгоміння, безлюддя довкола,

тільки сонце і простір, і сніг.

І котилося куль-покотьолом

моє серце в ведмежий барліг.

I зголілі модрини кричали,

тонко олень писався в імлі,

і зійшлися кінці і начала

на оцій чужинецькій землі [9, т. 3, тн. 2, 77]. 
Пейзажі при світлих споминах автора про Батьківщину сповнюються українською флорою: «На Колимі запахло чебрецем / i руто-м’ятою, i кропивою./ Кохана сестро, дякую! 3 любов'ю / паду в про тебе спогади лицем [9, т. 3, кн. 2, 80]. Або: Перепочиньте, харони мої.

Станьте під небом урочим, харони, тулиться лоно до білого лона в сотні громів гримотять солов'ї.

Перелетіть мене, перелетіть через дроти, паркани і горожі, о, Україно, до смертного дрожу чую тополя твоя шелестить [9, т. 3, кн. 1,138$]$.

У «Тигроловах» також наявний діалог про українську землю:

- А за Україною ви й не скучаєте? Та ви ії й не пам'ятаєте, мабуть?

- Чому ж? Пам'ятаю, але... Ти колись розкажеш, синку, як матимеш охоту, про тую Україну, як там живуть тепер. Дуже цікаво мені послухати. Я часто згадую своє дитинство і рідну землю. А надто, було, мати моя. Дуже вона тужила за рідною стороною та з того, мабуть, і померла. Все мріяла i просила, щоб ії відвезли вмирати додому, на рідну землю, на кладовище до батьків. Іноді й на мене находить туга, особливо, як згадаю матір. Але я й цю землю люблю. Тут-то зросла, тут віддалась, тут діток породила, та в цій землі чотирьох і поховала. I матір, і батька поховала тут. Ні, від цієї землі вже несила відірватись. Але й туди тягне. Як згадаю материні розмови, тії сади вишневі, тії степи широкі, ріки тихі, ночі ясні, зоряні і все, про що мати розповідала, та й сама бачила, хоч малою була... От я тут живу вік, а волошок тут не бачила. А там я з них, та барвінку, та з чорнобривців вінки на Купала плела. Нема їх тут. I васильків нема тут... Зберігся пучечок, з України завезений - якось нові переселенці подарували, - і пахнуть вони рідним краєм, тією Україною... Як напосядуть згадки про край той рідний, сонячний і тихий, - далебі, журба бере, так би й полетіла туди...» $[3,75]$. 
Саме такою запам'яталася Україна переселенцям. Лише Григорію відоме іï теперішнє: «Хотілось йому сказати цій матері, що немає вже того тихого краю, України тієї, ясної, сонячної. Що садки вишневі повирубувані, ріки збаламучені, степи сльозами обпоєні, і небо ясне людям потемніло... Але він мовчав. Нехай. Нехай любить її такою, якою пам'ятає» $[3,75]$.

Образ тогочасної України Іван Багряний розкриває за допомогою пасажирів ешелону, які діляться своєю безвихіддю, часом, змарнованим у пошуках роботи, кращої долі, у втечах від розкуркулювання: «Вагон говорив всіма діалектами його - Григорієвої - мови: полтавським, херсонським, чернігівським, одеським, кубанським, харківським... I ще й хтось кричав “Най би тя шляк трафив”, - нагадуючи про далеке Поділля... Ба, - тими діалектами говорив весь цей “експрес”, і то не тільки тепер, а, либонь, протягом цілої своєї історії. Основний контингент його пасажирів - Україна, ота зірвана 3 місця і кидана по всіх світах <..> Григорій слухав весь той гамір, зціпивши зуби, і йому паморочилась голова. Те, що він почав був забувати - ціла ота трагедія його народу - навалилась на нього всім тягарем, кидаючи серце, мов м'яч, у всі боки. Уся! Уся його Вітчизна ось так - на колесах позагеттю, розчавлена, розшматована, знеосіблена, в корості, в бруді... розпачі!.. Голодна!.. Безвихідна!.. Безперспективна!.»» [3, 174-177].

Далека стражденнаУкраїна завжди у Стусових думках і рядках:

Ми робим смерть. Лякливі тіні, ми робим смерть, ми робим смерть.

І те даруєм Україні, де все існує шкереберть [9, т. 3, кн. 1, 154].

Або:

I даленіє дальня Україна ошукана, оспала, навісна. Дивлюсь - і мало очі не пірву: невже тобі - ні племені, ні роду, за сині за моря лети по воду однаково - чи мертву чи живу [9, т. 3, кн. 1,44$]$. 
Вчинок Григорія Многогрішного символізує нескореність, патріотизм. Це шлях до самоідентифікації, а також спасіння для наступних поколінь, взірцем для яких має бути «відтворений образ того, хто не здався, хто лишився таки там. Образ, як символ непокірної і гордої молодості, символ тієї волелюбної і сплюндрованої за те Вітчизни...» $[3,16]$. М. Жулинський зазначає: «Григорій Многогрішний не скорився, не змирився зі своїм, насильницьки нав'язаним йому статусом в'язня жахливої системи i залишився людиною. Для Івана Багряного - людини і художника - це головне: переконати читача, упевнити його в тому, що за будь-яких обставин людина може (і повинна!) бути людиною» $[5,11]$.

Жіночі образи у творі також вирізняються своєю відважністю, свободолюбством. Сірчиха у широкому сенсі символізує природу української державності: «Розборкана - он яка. Скільки тієї мужності простої, скільки тієї певності, може, неусвідомленої, а звичайної, стихійної. І скільки тієї гордості волелюбної, природної, як оті могутні кряжі гір!» $[3,75]$.

Багряний, описуючи звичаї українців, розповідаючи про їхні умови життя, побут, особливості полювання у приамурській тайзі, акцентує і на відмінностях, спровокованих обставинами, долями: «Hi, це не в Слобожанському лузі! Це зовсім на другім кінці землі... А люди - ті самі. I не ті самі. Такі й не такі. Всім такі, лише одним не такі, - поглядом, життєвим тембром, іншою якістю. Ці - суворі і загартовані. Безжалісні стрільці, веселі і безпощадні звіролови, мускулясті диктатори в цій зеленій, первісній державі, хижі і горді завойовники цієї, ще не загнузданої стихії. Життя геть випекло 3 них сентиментальні риси і вайлувату ліниву млявість, насталивши їх, вигартувавши в безперервнім змаганні за своє існування...» $[3,111]$. Та все ж герої не нарікають на життя в чужині, вони впевнені, що цей «край працю любить та й винагороджує iї щедро» $[3,73]$.

Ось чому В. Чорногай, інтерпретуючи «Тигролови», йменує іï «Поемою всепереможного оптимізму» [10]. Слова ж Сірчихи «У сміливих щастя завжди є» стають своєрідним гаслом героїв роману Івана Багряного, а час $\mathrm{i}$ 
життя цього суворого сибірського краю залишаються вірними самі собі, набуваючи ознак універсальності: «Час собі йшов замріяною ходою по безбережному зеленому океану, осяяний сонячним блиском, сповнений буйної, веселкової молодості, озвучений гомоном птахів і звірят, і шумом кедрів вгорі, i таємничим шепотом листу, заквітчаний-закосичений цвітом. Час ішов по нетрях, час ішов по жилах - рухав у них кров, змушував серце тремтіти так, як тремтить лист під промінням сонця в діамантових росинках... То йшла молодість, і ні до кого їй нема ніякого діла. То йшло життя, тріумфуючи. Життя - як мерехтливий сонячний простір, як безмежна, заквітчана падь Голуба» [3, 139].

Оптимізм, наполегливість, нескореність - риси як самого Стуса (згадаймо слова поета в листі до сина від 25.04.1979 року: «...Або світ прийме мене таким, яким я є, як мене народила мати, - або вб’є, знищить мене. Але я - не поступлюся! I з кожної миті своєї, з кожного почуття й думки своєї зроблю свій портрет, тобто портрет цілого світу: хай знає цей світ, що душив, гнув мене, що я вижив, зберігся, доніс до людей усе, що хотів» [9, т. 6, кн. 1, 348]), так і квінтесенція його «Палімпсестів»:

$$
\begin{aligned}
& \text {...и щуе повернемось, } \\
& \text { обов'язково повернемось, } \\
& \text { бодай - } \\
& \text { ногами вперед, } \\
& \text { але: не мертві, } \\
& \text { але - не переможені, } \\
& \text { але - безсмертні [9, т. } 3 \text {, кн. 2, 16-17]. }
\end{aligned}
$$

Отже, у творах Івана Багряного та Василя Стуса образ сибірськодалекосхідного краю трактується як місце заслання, переселення, а також пов'язується 3 «духовним освоєнням» (своєрідним «воскресінням» (за Лотманом)), що є реалізацією дихотомії «своє-чуже»: віднайдення нового місия («Тигролови») чи повернення до рідного («Палімпсести»); його природа 
оприявнюється у творчості обох майстрів слова за допомогою констант відмінності від свого, українського, незвичності, екзотизму.

\section{ЛІТЕРАТУРА}

1. Азадовский М. К. Очерки литературы и культуры Сибири. Вып. 1. Иркутск : Иркутское областное издательство, 1947. 199 с.

2. Багряний згадував: «У 1932 році був заарештований за політичний (самостійницький український) ухил в літературі й політиці й ув'язнений в Харківській т. зв. внутрішній тюрмі ГПУ, де пробув 11 місяців в камері самотнього ув'язнення, а потім був засуджений на 5 років концтаборів. Присуд відбував в таборах т. зв. БАМЛАГУ. Терміну не добув, бо в 1937 році втік». Іван Багряний (1906-1963). - URL: http://www.ukrlit.vn.ua/info/xx/mm9ij.html. - Заголовок з екрану.

3. Багряний I. Тигролови. Морітурі. К. : Наук. думка, 2000. 368 с.

4. Горова Ю. Топос Сибіру у творчості Тараса Шевченка та польських романтиків. Слово $і$ час. 2003. № 3. С. 56-61.

5. Жулинський М. Іван Багряний. Слово і час. 1991. № 10. С. 7-13.

6. КлочекГ. Романи Івана Багряного «Тигролови» i «Сад Гетсиманський». Кіровоград : Степова Еллада, 1998. 80 с.

7. Лотман Ю. В школе поэтического слова. Пушкин. Лермонтов. Гоголь. М. : Просвещение, 1988. 352 с.

8. Сподарець М. П. Іван Багряний - письменник і громадянин. Х. : ХДУ, 1996. $104 \mathrm{c}$.

9. Стус В. Твори. У 4-х т. 6 кн. / голова ред. кол. М. Коцюбинська ; НАН України, Ін-т л-ри ім. Т. Г. Шевченка, Від. рукоп. фондів і текстології. Львів : Просвіта, 1994-1999.

10. Чорногай B. Поема всепереможного оптимізму: [Про роман «Тигролови»]. Новi дні. 1953. Ч. 41-42. черв. - лип.

11. Шевченко Т. Г. Повне зібрання творів : У 12 т. К. : Наук. думка, 2001. Т. 1. 782 с.

12. Эртнер E.H. Образ Сибири в русской литературе XIX века. URL: http://www.utmn.ru/frgf/No6/text16.htm. - Заголовок з екрану.

\section{REFERENCES}

1. Azadovskiy, M. Ocherki literaturyi i kulturyi Sibiri [Notes about syberian literature and culture], Vol. 1, Irkutsk : Irkutskoe oblastnoe izdatelstvo, 1947, 199 p. [In Russian].

2. Bahrianyi, Ivan (1906-1963) [Bahriany Ivan (1906-1963)]. URL: http://www.ukrlit.vn.ua/info/xx/mm9ij.html. [In Ukrainian].

3. Bahrianyi, I. Tyhrolovy. Morituri [Tyger hunters. Moritury], Kyiv: Naukova dumka, 2000. 368 p. [In Ukrainian].

4. Horova, Ju. Topos Sybiru u tvorchosti Tarasa Shevchenka ta polskykh romantykiv [Syberian topos in creations of Taras Shevchenko and polish romanticists], Slovo $i$ chas [Word and Time], 2003, No. 3, pp. 56-61 [In Ukrainian].

5. Zhulynskyi, M. Ivan Bahrianyi [Ivan Bahriany], Slovo i chas [Word and Time], 1991, No. 10, pp. 7-13 [In Ukrainian].

6. Klochek, H. Romany Ivana Bahrianoho «Tyhrolovy» $i$ «Sad Hetsymanskyi» [Novels "Tyger hunters" and "The Garden of Gethsemane], Kirovohrad : Stepova Ellada, 1998, 80 p. [In Ukrainian].

7. Lotman, Ju. V shkole poeticheskogo slova. Pushkin. Lermontov. Gogol [In the school of poetic word. Pushkin. Lermontov. Gogol], Moskva, Prosveschenie, 1988, 352 p [In Russian].

8. Spodarets, M. P. Ivan Bahrianyi - pysmennyk i hromadianyn [Ivan Bahriany - writer and citizen], Kharkiv: KhDU, 1996, 104 p. [In Ukrainian]. 
9. Stus, V. Tvory. U 4-kh tomakh, 6 knyhakh [Works. In 4 volumes, 6 books], Lviv : Prosvita, 1994-1999 [In Ukrainian].

10. Chornohai, V. Poema vseperemozhnoho optymizmu: (Pro roman «Tyhrolovy») [The poem of all-conquering optimism: (About the novel "Tyger hunters"], Novi dni [New Days], 1953, Vol. 41-42, cherven' - lypen' [In Ukrainian].

11. Shevchenko, T. H. Povne zibrannia tvoriv: U 12 t. [Full selection of works: in 12 volumes], Kyiv: Naukova dumka, 2001, Vol. 1, 782 p [In Ukrainian].

12. Ertner, Je. N. Obraz Sibiri v russkoy literature XIX veka [Image of Syberia in russian literature of XIX century]. URL: http://www.utmn.ru/frgf/No6/text16.htm. [In Russian].

\section{АННОТАЦИЯ}

Наталья Сквира. Украина, Сибирь и Дальний Восток в творчестве Ивана Багряного и Василия Стуса

В статье на примере романа «Тигроловы» Ивана Багряного и сборника стихов Василия Стуса «Палимпсесты» прослеживаются особенности топоса Сибири, Дальнего Востока и Украины. Сибирь и Дальний Восток изображаются как место ссылки, связываются с духовным освоением, нахождением нового места («Тигроловы») или возвращением к родному («Палимпсесты»). В творчестве обеих писателей этот топос демонстрирует отличие от своего, украинского.

Ключевые слова: топос, Сибирь, Дальний Восток, Украина, дихотомия «своёчужоё».

\section{ABSTRACT \\ Natalia Skvira. Ukraine, Siberia and the Far East in the function of Ivan Bagryaniy and Vasyl Stus}

The tops of Siberia, Far East and Ukraine in Ivan Bagryaniy's "Tiger-hunters" and Vasyl Stus's "Palimpsests" are examined in the article. On the basis of a comparison of multi-genre works, the similarity of topos of Siberia, Far East to various authors is established, primarily due to their coercive nature of staying in these places, the unusual nature of the landscape, the living conditions. Despite the complexity of the conditions of stay, the authors of the analyzed works do not lose optimism, trying to convince the reader that a strange land can become a shelter for them, reward them for hard work. Taking into account the genre specificity of the novel "Tigerhunters" by Ivan Bagryaniy, the author of the article concludes that the novel form enables the prose writer in detail to panoramic the realities of life and life of tigrolos. The lyrics of the collection Vasyl Stus "Palimpsests" mostly convey the impression of another's land, its strict nature, which appears to be a silent witness to events. At the same time, it is felt and fascination with pristine beauty, because the poet involves natural phenomena in their interlocutors.

Siberian and Far-Eastern region is interpreted as a place of exile, resettlement, and is also associated with «spiritual development» (a kind of «resurrection» (Yu. Lotman), which is an implementation of the dichotomy "own-alien": new location ("Tiger-hunters") or a returning to the native ("Palimpsests"); nature is revealed in the works of both writers with the constants of strangeness, exoticism and it differs from the Ukrainian one. Bagryaniy, describing the customs of Ukrainians, telling about their conditions of life and features of hunting in the Amur tail, accentuates the differences caused by circumstances, fractions

Key words: topos, Siberia, Far East, Ukraine, the dichotomy «own-alien». 